\title{
An update on the epidemiologic situation of bovine brucellosis in the state of Espírito Santo, Brazil
}

\author{
Atualização da situação epidemiológica da brucelose bovina no \\ Estado do Espírito Santo, Brasil
}

\author{
Eleine Kuroki Anzai ${ }^{1 *}$; Daniele da Costa ${ }^{2}$; Alba Luisa Pereira Ribeiro Said ${ }^{3}$; José \\ Henrique Hildebrand Grisi-Filho4; Marcos Amaku; Ricardo Augusto Dias"; \\ Fernando Ferreira ${ }^{4}$; Jason Onell Ardila Galvis ${ }^{1}$; Vitor Salvador Picão Gonçalves ${ }^{5}$; \\ Marcos Bryan Heinemann ${ }^{4}$; Evelise Oliveira Telles ${ }^{4}$; José Soares Ferreira Neto ${ }^{4}$
}

\begin{abstract}
A cross-sectional study was carried out between January 2012 and May 2014 to estimate the prevalence of bovine brucellosis in the state of Espírito Santo, Brazil. This study was carried out 11 years after the implementation of the immunization program for heifers with a vaccine derived from the S19 strain of Brucella abortus. The state was divided into two regions. Three hundred farms from each region, with reproductive activity, were randomly chosen and included as primary sample units. A fixed number of cows were randomly selected and tested for antibodies against Brucella spp. A farm was considered to be infected when at least one female tested positive for Brucella spp. In the selected farms, an epidemiological questionnaire based survey, focused on herd traits as well as husbandry and sanitary practices, was conducted, to evaluate the factors associated with the risk of infection. The overall prevalence of infected herds was $9.3 \%$ (95\% confidence interval, $95 \% \mathrm{CI}=7.1-11.8 \%)$, varying from $8.7 \%(95 \% \mathrm{CI}=5.7-12.6 \%)$ in region 2 to $9.7 \%(95 \% \mathrm{CI}=6.8-13.4 \%)$ in region 1 . There was no significant difference in the prevalence between the regions. The apparent prevalence of Brucella spp. positive farms across the regions and the state was similar to the prevalence observed 11 years earlier. The prevalence of positive animals was 3.8\% $(95 \% \mathrm{CI}=0.9-10.1 \%)$, varying from $1.5 \%(95 \% \mathrm{CI}=0.8$ $2.4 \%)$ in region 1 to $7.9 \%(95 \% \mathrm{CI}=1.9-20.3 \%)$ in region 2 , without a significant difference between the regions. There was no difference in the number of Brucella spp. positive animals after 11 years of the immunization program. The risk factors associated with brucellosis were (i) more than 10 cows per herd ( $\mathrm{OR}=5.0 ; 95 \% \mathrm{CI}=2.5-11.1)$ and (ii) equipment, feedstock, or personnel sharing $(\mathrm{OR}=2.2$; $95 \% \mathrm{CI}=1.1-4.2)$. The state of Espírito Santo should seek systematic vaccination coverage targeting more than $80 \%$ of the eligible heifers. An efficient animal health program, which educates the farmers to test replacement animals for brucellosis before introducing them to their herds, to avoid equipment, personnel or feedstock sharing with farms of unknown sanitary conditions, and to increase awareness of the importance of good sanitary procedures during artificial insemination, should be implemented.

Key words: Bovine. Brucellosis. Prevalence. Risk factors. Espírito Santo. Brazil.
\end{abstract}

\footnotetext{
${ }^{1}$ Discentes do Programa de Pós-Graduação. Departamento de Medicina Veterinária Preventiva e Saúde Animal, Faculdade de Medicina Veterinária e Zootecnia, Universidade de São Paulo, USP, São Paulo, SP, Brasil. E-mail: elanzai@hotmail.com; jason. ardila@usp.br

${ }^{2}$ Médica Veterinária, Instituto de Defesa Agropecuária e Florestal do Espírito Santo, IDAF, Vitória, ES, Brasil. E-mail: daniele. costa@idaf.es.gov.br

${ }^{3}$ Fiscal da Superintendência Federal de Agricultura do Espírito Santo, SFA-ES, Vitória, ES, Brasil. E-mail: alba.said@agricultura. gov.br

4 Profs., Departamento de Medicina Veterinária Preventiva, Faculdade de Medicina Veterinária e Zootecnia, USP, São Paulo, SP, Brasil. E-mail: grisi@vps.fmvz.usp.br; amaku@vps.fmvz.usp.br; dias@vps.fmvz.usp.br; fernando@vps.fmvz.usp.br; marcosbryan@usp.br; bufalo@usp.br; jsoares@vps.fmvz.usp.br

5 Prof., Faculdade de Agronomia e Medicina Veterinária, Universidade de Brasília, UNB, Brasília, DF, Brasil. E-mail: vitorspg@ unb.br

* Author for correspondence
} 


\section{Resumo}

Para estimar a prevalência e os fatores de risco da brucelose bovina no Estado do Espírito Santo (Brasil), foi realizado um estudo transversal entre janeiro de 2012 e maio de 2014. Esse estudo foi realizado 11 anos após a implementação de um programa de imunização em novilhas utilizando uma vacina derivada da estirpe S19 de Brucella abortus. O estado foi dividido em duas regiões. Trezentas propriedades com atividade reprodutiva foram aleatoriamente selecionadas em cada região e incluídas como unidades primárias de amostragem. Um número fixo de fêmeas adultas foi aleatoriamente selecionado em cada propriedade. Os animais foram testados para anticorpos contra Brucella spp. Um questionário epidemiológico foi aplicado em cada propriedade selecionada, para avaliar os fatores associados com o risco de infecção. A prevalência aparente de propriedades infectadas foi de $9,3 \%$ (intervalo de confiança $95 \%$, IC $95 \%=7,1-11,8 \%$ ), variando de $8,7 \%$ (IC $95 \%=5,7-12,6 \%$ ) na região 2 a $9,7 \%$ (IC $95 \%=6,8-$ $13,4 \%$ ) na região 1 . Não foi encontrada diferença estatística na prevalência entre as regiões estudadas. A prevalência de propriedades positivas para Brucella spp. foi similar à prevalência observada 11 anos atrás, comparando tanto as regiões quanto o estado. A prevalência aparente de animais positivos encontrada foi de 3,8\% (IC 95\% = 0,9-10,1\%), variando de 1,5\% (IC 95\% $=0,8-2,4 \%$ ) na região 1 a 7,9\% (IC $95 \%=1,9-20,3 \%$ ) na região 2, sem diferença significativa entre as regiões. Não foi houve mudança no número de animais positivos para Brucella spp depois de 11 anos de implementação do programa de imunização. Os fatores de risco associados com a brucelose foram (i) mais de 10 fêmeas adultas no rebanho e (ii) compartilhamento de equipamento, material ou pessoal. O Estado do Espírito Santo deve buscar atingir uma cobertura vacinal de pelo menos $80 \%$ das novilhas, de maneira sistemática, além de implementar um programa de saúde animal eficiente, educando os fazendeiros a testar animais para brucelose antes de sua introdução em seus rebanhos e a evitar o compartilhamento de equipamento, pessoal e material com propriedades de condição sanitária incerta.

Palavras-chave: Bovino. Brucelose. Prevalência. Fatores de risco. Espírito Santo. Brasil.

\section{Introduction}

Bovine brucellosis is a chronic zoonotic disease caused by Brucella abortus that causes economic losses to farmers involved in beef and milk production (ALVES et al., 2015). Although the disease can also be transmitted by B. melitensis, it has never been isolated in Brazil (POESTER et al., 2002). The main symptom of the disease is an abortion of the fetus during the second half of the gestation. The bacteria are transmitted through abortion products and vaginal discharge (PAULIN; FERREIRA NETO, 2003). The disease is usually endemic and is widespread over large territories connected by commercial relations, especially animal trade (MIKOLON et al., 1998).

In the year 2001, the Brazilian Ministry of Agriculture, Livestock and Food Supply (MAPA) launched the National Program for the Control and Eradication of Animal Brucellosis and Tuberculosis (PNCEBT). The program was aimed at the reduction of the negative impact of bovine brucellosis and tuberculosis on human health and the promotion of competitiveness in the national livestock industry (LAGE et al., 2006).

The control measures introduced by PNCEBT include compulsory vaccination of bovine and buffalo heifers, aged between 3 and 8 months, against brucellosis with the S19 vaccine. This was implemented throughout the country (except the state of Santa Catarina). The program also included the voluntary certification of brucellosis-free farms (LAGE et al., 2006). The farmers pay for most of these activities such as vaccination of heifers, diagnostic tests, and veterinary services. The official veterinary service is only responsible for auditing the entire system.

Along with the establishment of the PNCEBT, epidemiological surveys, which included farms with reproductive activity as primary sample units, were also conducted in 18 Brazilian states (covering 85\% of the total bovine population). The prevalence of brucellosis infected herds varied from $0.32 \%$ in the state of Santa Catarina to $41.5 \%$ in the state of Mato Grosso do Sul (ALVES et al., 2009; AZEVEDO 
et al., 2009; BORBA et al., 2013; CHATE et al., 2009; DIAS et al., 2009a, 2009b; GONÇALVES et al., 2009a, 2009b; KLEIN-GUNNEWIEK et al., 2009; MARVULO et al., 2009; NEGREIROS et al., 2009; OGATA et al., 2009; ROCHA et al., 2009; SIKUSAWA et al., 2009; SILVA et al., 2009; VILLAR et al., 2009; ALMEIDA et al., 2016; CLEMENTINO et al., 2016). The states of Santa Catarina, São Paulo, Minas Gerais, Rondônia, Mato Grosso, Mato Grosso do Sul, and Rio Grande do Sul carried out a second study on the prevalence of brucellosis. Of the 7 states included in this study a decrease in the prevalence of infected herds, as a consequence of the immunization program, was observed only in the states of Mato Grosso, Mato Grosso do Sul, Minas Gerais, and Rondônia (BARDDAL et al.; 2016; BAUMGARTEN et al., 2016; DIAS et al., 2016; INLAMEA et al., 2016; LEAL FILHO et al., 2016; OLIVEIRA et al., 2016; SILVA et al., 2016).

In the year 2002, the prevalence of infected herds in the state of Espírito Santo was 9\% (95\% confidence interval, 95\% CI $=7.0-11.6 \%$ ) and the prevalence of infected animals was 3.5\% $(95 \% \mathrm{CI}=$ $1.9-6.4 \%$ ) (AZEVEDO et al., 2009). At the time, it was recommended that the state should organize an effective immunization program using a vaccine derived from the S19 strain and ensure that the vaccine was annually administered to more than $80 \%$ of the eligible heifers (AMAKU et al., 2009).

The present study aimed to repeat the epidemiological survey in the state of Espírito Santo, 11 years after the implementation of the mandatory vaccination of heifers against brucellosis, in order to verify the efficacy of the immunization program and enable the management and adjustment of the animal health policy.

\section{Material and Methods}

\section{Sample design}

The present study was designed by the Brazilian Ministry of Agriculture, Livestock and Food
Supply (MAPA), the Collaborator Centre in Animal Health of the School of Veterinary Medicine of the University of São Paulo (FMVZ-USP), and the Animal Health Service of the State of Espírito Santo (Instituto de Defesa Agropecuária e Florestal do Espírito Santo - IDAF). The fieldwork was performed between January 2012 and May 2014 by the IDAF staff members, who were trained in standardized procedures. The present work replicated the methodology adopted by a previous study, performed 10 years earlier (AZEVEDO et al., 2009).

In order to characterize regional differences in the epidemiological parameters associated with bovine brucellosis, the state of Espírito Santo was divided into two regions. The classification was based on the system proposed by Azevedo et al. (2009), which is based on livestock production systems, livestock management practices, herd size, and trade systems. This division of regions took into consideration the operational and logistic capacity of the IDAF to perform the fieldwork, which is dependent on the distribution of its regional offices. A map of the livestock regions was prepared using the ArcGIS 10.0 software.

In each region, a cross-sectional study was performed to estimate the herd level and animal level prevalence of bovine brucellosis using a twostage sampling method. In the first stage, a predetermined number of farms with reproduction activity were randomly selected (primary sampling units). In the second stage, a pre-determined number of bovine females, older than two years of age, were randomly selected (secondary sampling units).

In farms with more than one herd, the largest, economically important herd was chosen. The animals from the chosen herds were exposed to the same animal management procedures, i.e. were exposed to the same risk factors. The choice of the primary sampling units was based on the official farm registry database. When the IDAF staff members were unable to visit a selected farm, a replacement farm was randomly selected. 
The number of selected farms per livestock region was estimated using the simple random sample formula, proposed by Thrusfield (2007) and Noordhuizen et al. (2001):

$$
N=\frac{Z_{\alpha}^{2} * P^{*}(1-P)}{d^{2}}
$$

where, $N$ denotes the sample size, $Z_{\alpha}$ is the normal distribution value at a confidence level of $95 \%, P$ is the expected prevalence (20\%), and $d$ is the absolute error $(5 \%)$.

The choice of the secondary sampling units was aimed at the appropriate classification of a farm as positive or negative. To achieve this, the herd sensibility and specificity concept was used (DOHOO et al., 2003). The values for sensitivity and specificity for the test protocol were $95 \%$ and $99.5 \%$ respectively (FLETCHER et al., 1998), and 20\% for the expected prevalence. The calculations were performed using the Herdacc version 3 software and the selected sample size was the one that allowed a herd sensibility and specificity of greater than $90 \%$. Thus, 10 animals were sampled from farms with less than 99 females older than two years of age, and 15 animals were selected from farms with more than 99 females older than two years of age. If the selected herd was smaller than the required sample, all animals were sampled. The sampling method for the selection of females was systematic. A farm was considered to be infected when at least one animal tested positive for Brucella spp.

\section{Test protocol}

The test protocol consisted of animal screening using the Rose Bengal test, followed by an additional testing of the positive animals using the complement fixation test developed by Alton et al. (1988). The blood was collected through a jugular vein puncture using a sterile needle connected to a pre-labeled vacuum tube. Sera were stored at $-20^{\circ} \mathrm{C}$ in plastic microtubes, until further testing.

\section{Estimation of prevalence}

The sample design allowed us to estimate herd and animal level prevalence in the state of Espírito Santo and in the individual livestock regions as well. The apparent prevalence and the respective confidence intervals were estimated following the method proposed by Lumley (2004). All calculations were statistically weighted (DOHOO et al., 2003). The statistical weight of each farm $\left(W_{f}\right)$ in the calculation of the positive herd prevalence across the entire state was:

$$
W_{f}=\frac{\text { number of farms in the region }}{\text { number of sampled farms in the region }}
$$

The statistical weight of each positive bovine female older than two years of age $\left(W_{a}\right)$ in the calculation of animal level prevalence across the entire state was:

$$
\begin{gathered}
W_{a}=\frac{\text { females } \geq 2 \text { years in the farm }}{\text { sampled females } \geq 2 \text { years in the farm }} \times \\
\text { females } \geq 2 \text { years in the region }
\end{gathered}
$$

females $\geq 2$ years in the sampled farms of the region

In the above expression, the first term refers to the statistical weight of each sampled animal in the farm and the second term refers to the statistical weight of each farm in the livestock region.

The prevalence estimates and the respective $95 \%$ confidence intervals $(95 \% \mathrm{CI})$ were calculated using the R software (R DEVELOPMENT CORE TEAM, 2012) along with the "survey" package (LUMLEY, 2004).

\section{Analysis of risk factors}

A questionnaire-based survey was conducted at each sample farm in order to generate data on the livestock management practices. All information generated was inserted into a database. 
In this cross-sectional study, risk factors such as production system (meat, milk, mixed), raising system (extensive, degree of confinement), artificial insemination, cattle breeds, number of cows older than two years of age, total herd size, presence of other domesticated species, presence of wild species, destination of the placenta and aborted fetuses, animal trade, vaccination against brucellosis, slaughter in the farm, pasture sharing, indirect contact between farms, flooded pastures, breeding paddock, and veterinary assistance were assessed.

These variables were organized based on a scale of increasing risk. A re-categorization was performed when necessary. The category with the lowest risk was always considered as baseline for comparisons with the other categories. Quantitative variables were categorized using the median as the cutoff.

An exploratory univariate analysis was performed using the chi-square $\left(\chi^{2}\right)$ or Fisher exact test with all variables, including the data from the entire state. Risk factors with a significance level of less than 0.20 were selected for further multivariate analysis using logistic regression, according to Hosmer and
Lemeshow (2000). All calculations were made using the $\mathrm{R}$ software (R DEVELOPMENT CORE TEAM, 2012).

\section{Results}

The state of Espírito Santo was divided into two livestock regions (Figure 1), based on the classification proposed by Azevedo et al. (2009).

The apparent herd level prevalence of bovine brucellosis in the state of Espírito Santo was estimated to be $9.3 \%$ (95\% CI $=7.1-11.8 \%)$, varying from $8.7 \%(95 \% \mathrm{CI}=5.7-12.6 \%)$ in region 2 to $9.7 \%(95 \% \mathrm{CI}=6.8-13.4 \%)$ in region 1 . However, no significant difference was observed between the regions (Table 1).

Moreover, no significant differences in the herd level prevalence between farm enterprises (beef, mixed and dairy) at each region, and between regions for each farm enterprise were observed (Table 2). This indicates that the disease is evenly distributed among beef, dairy, and mixed farms, within and between regions.

Figure 1. Map of the state of Espírito Santo showing the division of livestock regions used in the current study.
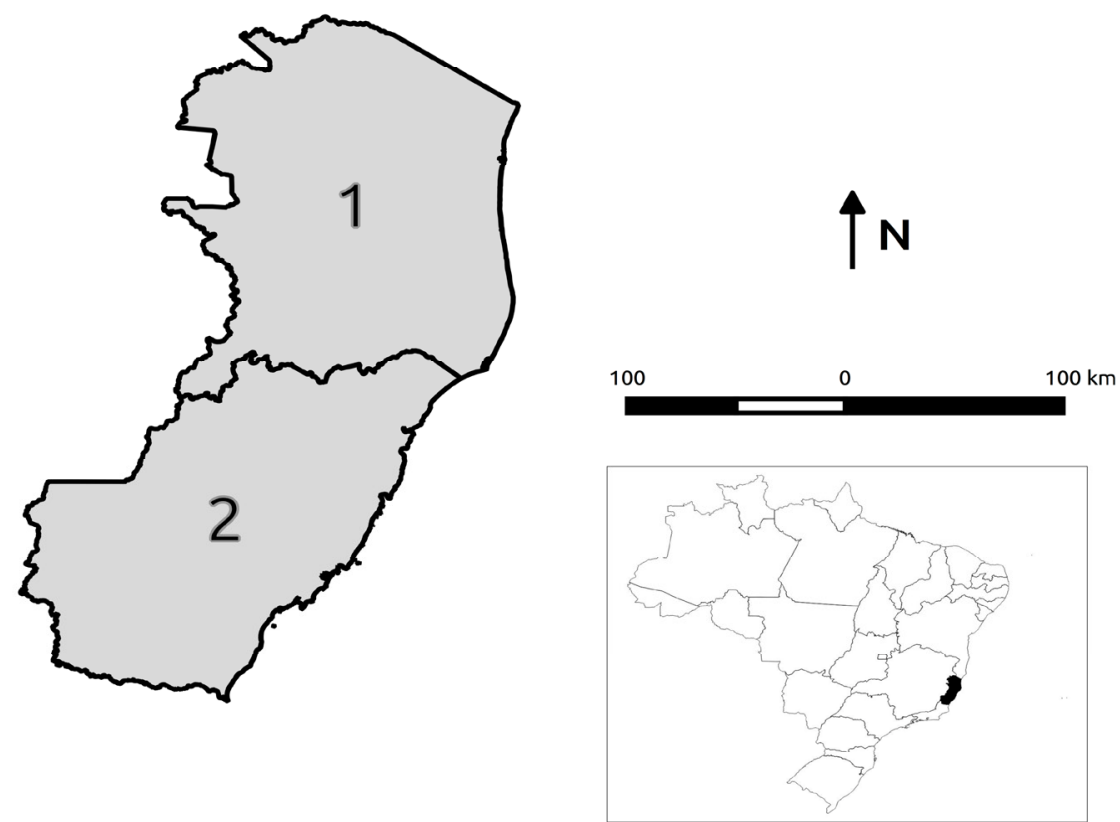
Table 1. Apparent herd level prevalence of bovine brucellosis in the state of Espírito Santo.

\begin{tabular}{cccccc}
\hline Region & $\begin{array}{c}\text { Farms with reproductive } \\
\text { activities }\end{array}$ & Sampled farms & Positive farms & Prevalence (\%) & 95\% CI (\%) \\
\hline 1 & 17,496 & 349 & 34 & 9.7 & $6.8-13.4$ \\
2 & 15,100 & 288 & 25 & 8.7 & $5.7-12.6$ \\
\hline Total & 32,596 & 637 & 59 & 9.3 & $7.1-11.8$ \\
\hline
\end{tabular}

Table 2. Apparent herd level prevalence of bovine brucellosis, based on the type of farm enterprise, in the state of Espírito Santo.

\begin{tabular}{cccccccccc}
\hline \multirow{2}{*}{ Region } & \multicolumn{3}{c}{ Beef cattle } & \multicolumn{3}{c}{ Dairy cattle } & \multicolumn{3}{c}{ Mixed cattle } \\
\cline { 2 - 10 } & $\mathrm{n}$ & $\%$ & $95 \%$ CI & $\mathrm{n}$ & $\%$ & $95 \%$ CI & $\mathrm{n}$ & $\%$ & $95 \%$ CI \\
\hline 1 & $6 / 38$ & 15.8 & $6.0-31.3$ & $22 / 201$ & 11.0 & $7.0-16.1$ & $6 / 106$ & 5.7 & $2.1-11.9$ \\
2 & $1 / 30$ & 3.3 & $0.1-17.3$ & $18 / 195$ & 9.2 & $5.6-14.2$ & $6 / 62$ & 9.7 & $3.6-19.9$ \\
\hline
\end{tabular}

The apparent prevalence of brucellosis positive $\quad(95 \% \mathrm{CI}=0.8-2.4 \%)$ in region 1 to $7.9 \%(95 \%$ cows in the state of Espírito Santo was estimated to $\mathrm{CI}=1.9-20.3 \%$ ) in region 2, without a significant be $3.8 \%(95 \% \mathrm{CI}=0.9-10.1 \%)$, varying from $1.5 \%$ difference between the regions (Table 3$)$.

Table 3. Apparent prevalence of brucellosis positive bovine females, above two years of age, in the state of Espírito Santo.

\begin{tabular}{cccccc}
\hline \multirow{2}{*}{ Region } & $\begin{array}{c}\text { Females } \\
\geq 2 \text { years of age }\end{array}$ & $\begin{array}{c}\text { Sampled females } \\
\geq 2 \text { years of age }\end{array}$ & Positive animals & Prevalence (\%) & 95\% CI (\%) \\
\hline 1 & 660,512 & 2,915 & 43 & 1.5 & $0.8-2.4$ \\
2 & 383,789 & 2,152 & 40 & 7.9 & $1.9-20.3$ \\
Total & $1,044,301$ & 5,067 & 83 & 3.8 & $0.9-10.1$ \\
\hline
\end{tabular}

Figure 2 shows the comparison between the animal level and herd level prevalence of brucellosis estimated from this study and the results obtained from a previous study conducted in 2002 (AZEVEDO et al., 2009).

The results from the univariate analysis, showing risk factors with $p<0.20$, are presented in Table
4. The results from the multivariate analysis are presented in Table 5. The final multivariate model indicated two risk factors: more than 10 adult females per herd $(\mathrm{OR}=5.0 ; 95 \% \mathrm{CI}=2.5-11.1)$ and equipment, feedstock or personnel sharing $(\mathrm{OR}=$ $2.2 ; 95 \% \mathrm{CI}=1.1-4.2$ ). 
Figure 2. A comparison of the animal (Left) and herd (Right) level prevalence of bovine brucellosis between 2002* and 2013 (present study) in the state of Espírito Santo. Horizontal bars indicate the 95\% confidence interval.

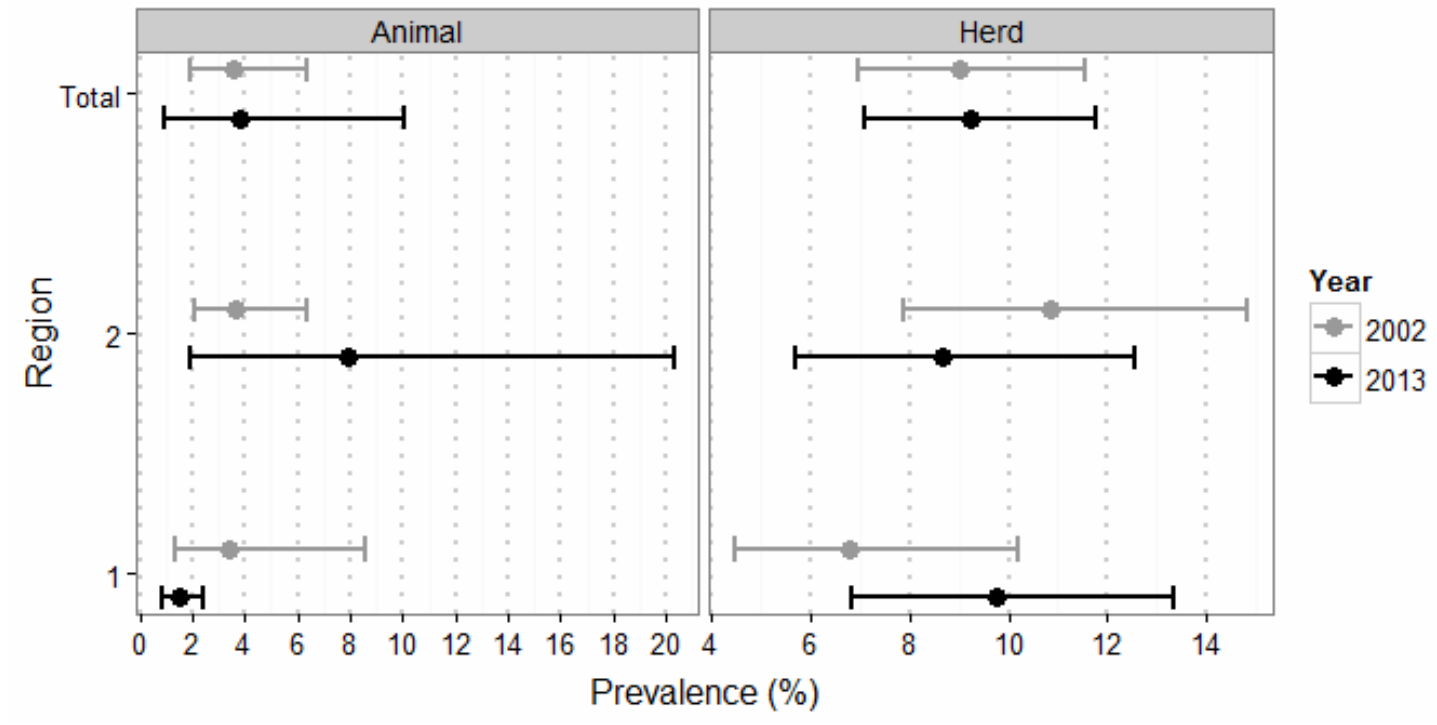

*(AZEVEDO et al., 2009).

Table 4. Univariate analysis of the risk factors associated with bovine brucellosis in the state of Espírito Santo.

\begin{tabular}{lccc}
\hline Variable & $\begin{array}{c}\text { Proportion of } \\
\text { infected herds }\end{array}$ & $\%$ & $\mathrm{p}$ \\
\hline Number of females $\geq 2$ years & $9 / 285$ & 3.2 & $<0.001$ \\
$1-10^{*}$ & $50 / 352$ & 14.2 & \\
$\geq 10$ & & & \\
Presence of calving paddock & $29 / 428$ & 6.8 & 0.002 \\
No & $30 / 204$ & 14.7 & \\
Yes & & & \\
Vaccination against bovine brucellosis & $3 / 116$ & 2.6 & 0.004 \\
No & $56 / 517$ & 10.8 & \\
Yes & & & \\
Occurrence of abortion** & $39 / 500$ & 7.8 & 0.008 \\
No & $17 / 102$ & 16.7 & \\
Yes & & & \\
Milking type & $10 / 87$ & 11.5 & 0.009 \\
Does not milk & $3 / 16$ & 18.8 & \\
Milking parlor & $11 / 55$ & 20.0 & \\
Milking machine & $34 / 460$ & 7.4 & \\
Manual & & & \\
Perform bovine tuberculosis tests & $45 / 555$ & 8.1 & 0.011 \\
No & $14 / 79$ & 17.7 & \\
Yes & & & \\
Equipment, feedstock or personnel sharing & $45 / 554$ & 8.1 & 0.015 \\
No & $14 / 83$ & 16.9 & \\
Yes & &
\end{tabular}


continuation

Milk cooling

No

$28 / 366$

7.7

12.9

Acquisition of breeding animals**

No

$29 / 386$

7.5

Yes

$29 / 240$

12.1

Perform bovine brucellosis tests

No

$45 / 531$

8.5

Yes

14 / 99

14.1

Artificial insemination

No

$44 / 516$

$15 / 109$

8.5

13.8

Sharing pasture

No

$46 / 533$

8.6

Yes

$13 / 102$

12.7

*Median. **During the previous 12 months.

Table 5. Final multivariate model of the risk factors for bovine brucellosis in the state of Espírito Santo.

\begin{tabular}{|c|c|c|c|}
\hline Variable & Odds ratio & $95 \% \mathrm{CI}$ & $\mathrm{p}$ \\
\hline \multicolumn{4}{|c|}{ Number of females $\geq 2$ years of age } \\
\hline $1-9$ (reference category) & - & - & - \\
\hline$\geq 10$ & 5.01 & $2.53-11.08$ & $<0.001$ \\
\hline \multicolumn{4}{|c|}{ Equipment, feedstock or personnel sharing } \\
\hline No (reference category) & - & - & - \\
\hline Yes & 2.21 & $1.10-4.21$ & 0.020 \\
\hline
\end{tabular}

$\mathrm{r}^{2}=4.9 \%$.

\section{Discussion}

Bovine brucellosis is prevalent in herds all over the state, irrespective of the location and the type of enterprise. No significant difference in the prevalence of brucellosis infected herds was observed between the 2002 (AZEVEDO et al., 2009) and 2013 serological surveys (present study), both at the regional level and for the entire state. Similarly, no significant differences were observed in the prevalence in animals. A comparison of the positive-farm and positive-animal prevalence between the 2002 (AZEVEDO et al., 2009) and 2013 (present study) surveys is shown in Figure 2.
The confidence interval for animal level prevalence in region 2 observed in the present study is unusually high. This is due to the classification of a large farm (with 2,300 females, 24 months or older) as positive. Since this farm had 3 infected animals out of $15(20 \%)$ and every sampled animal in this farm accounted for over 150 animals (following statistical weighting), this contributed a large standard error to the complex survey estimate, thereby increasing the confidence interval (Figure 2).

The final multivariate model indicated two risk factors: more than 10 cows per herd $(\mathrm{OR}=5.01$; $95 \% \mathrm{CI}=2.53-11.08)$ and equipment, feedstock, 
or personnel sharing $(\mathrm{OR}=2.21 ; 95 \% \mathrm{CI}=1.10$ 4.21) (Table 5). The practice of sharing equipment, feedstock, or personnel is an obvious risk factor, since bovine brucellosis can spread through fomites.

The association between the herd size and brucellosis has been reported in the past by many researchers (KELLAR et al., 1976; NICOLETTI, 1980; SALMAN; MEYER, 1984)particularly those who made purchases from other herds or from cattle dealers. Infected herds had a lower level of vaccination than noninfected herds. However, the percentage vaccinated was highly variable in each group. Vaccination per se did not appear to adversely influence the interpretation of serological test results nor did it appear to protect the individual animal. Once infected, the time required to become free of brucellosis was increased by large herd size and/or loose housing. Closed herds also took longer to become brucellosis free than more open herds. The percentage of animals removed from the herd was increased by active abortion. Those herds with multiple serological reactors (positives and questionables. Similar findings were also reported in the Brazilian states of Mato Grosso, Mato Grosso do Sul, Rio de Janeiro, Sergipe, Tocantins and in a previous study carried out in São Paulo in 2001 (CHATE et al., 2009; DIAS et al., 2009b; KLEINGUNNEWIEK et al., 2009; NEGREIROS et al., 2009; OGATA et al., 2009; SILVA et al., 2009). Some characteristics of the larger herds may facilitate the transmission of brucellosis, especially the higher frequency of animal replacement, difficulty in implementing disease control measures, and the dynamics of the disease itself (CRAWFORD et al., 1990). Christie (1969) observed that the increased herd size results in an increased probability of occurrence, persistence of infection, and difficulty in eradicating brucellosis. Therefore, a larger herd size presents a higher risk of brucellosis introduction and a higher probability of intra-herd dissemination.

\section{Conclusion}

No difference was observed in the herd level prevalence of brucellosis after more than 10 years of mandatory immunization. The state of Espírito Santo should target systematic vaccination of more than $80 \%$ of the eligible heifers. An efficient animal health education program educating farmers to test replacement animals for brucellosis, prior to introduction in their herds and to avoid equipment, personnel or feedstock sharing with farms of unknown sanitary conditions, should be implemented.

\section{Acknowledgements}

The authors acknowledge the logistical and financial support from MAPA, IDAF-ES, CNPq and FAPESP.

\section{References}

ALMEIDA, E. C.; FREITAS, A. A.; PONTUAL, K. A. Q.; SOUZA, M. M. A.; AMAKU, M.; DIAS, R. A.; FERREIRA, F.; TELLES, E. O.; HEINEMANN, M. B.; GONÇALVES, V. S. P.; EVÊNCIO NETO, J.; MARVULO, M. F. V.; GRISI-FILHO, J. H. H.; FERREIRA NETO, J. S.; SILVA, J. C. R. Prevalence and associated risk factors for bovine brucellosis in the state of Pernambuco, Brazil. Semina: Ciências Agrárias, Londrina, v. 37, n. 5, p. 3413-3424, 2016. Suplemento 2.

ALTON, G. G.; JONES, L. M.; ANGUS, R. D.; VERGER, J. M. Techniques for the brucellosis laboratory. 75007 Paris: Institut National de la Recherche Agronomique (INRA), 1988. $190 \mathrm{p}$.

ALVES, A. J. S.; GONÇALVES, V. P. S.; FIGUEIREDO, V. C. F.; LÔBO, J. R.; BAHIENSE, L.; AMAKU, M.; FERNANDO, F.; FERREIRA NETO, J. S.; DIAS, R. A. Situação epidemiológica da brucelose bovina no Estado da Bahia. Arquivo Brasileiro de Medicina Veterinária e Zootecnia, Belo Horizonte, v. 61, p. 6-13, 2009. Suplemento 1.

ALVES, A. J. S.; ROCHA, F.; AMAKU, M.; FERREIRA, F.; TELLES, E. O.; GRISI-FILHO, J. H. H.; FERREIRA NETO, J. S.; ZYLBERSZTAJN, D.; DIAS, R. A. Economic analysis of vaccination to control bovine brucellosis in the States of Sao Paulo and Mato Grosso, 
Brazil. Preventive Veterinary Medicine, Amsterdam, v. 118, n. 4, p. 351-358, 2015.

AMAKU, M.; DIAS, R.; FERREIRA NETO, J.; FERREIRA, F. Modelagem matemática do controle de brucelose bovina por vacinação. Arquivo Brasileiro de Medicina Veterinária e Zootecnia, Belo Horizonte, v. 61, p. 135-141, 2009. Suplemento 1.

AZEVEDO, S. S.; FERREIRA NETO, J. S.; DIAS, R. A.; FERREIRA, F.; AMAKU, M.; FIGUEIREDO, V. C. F.; LÔBO, J. R.; GONÇALVES, V. S. P.; SOUZA, A. C.; VASCONCELLOS, S. A. Situação epidemiológica da brucelose bovina no Estado do Espírito Santo. Arquivo Brasileiro de Medicina Veterinária e Zootecnia, Belo Horizonte, v. 61, p. 19-26, 2009. Suplemento 1.

BARDDAL, J. E. I.; SANTOS, J. C. Q.; LOPES, I. F.; FERREIRA NETO, J. S.; FERREIRA, F.; AMAKU, M.; DIAS, R. A.; TELLES, E. O.; GRISI-FILHO, J. H. H.; HEINEMANN, M. B.; GONÇALVES, V. S. P.; AGUIAR, D. M. Effect of vaccination in lowering the prevalence of bovine brucellosis in the state of Mato Grosso, Brazil. Semina: Ciências Agrárias, Londrina, v. 37, n. 5, p. 3479-3492, 2016. Suplemento 2.

BAUMGARTEN, K. D.; VELOSO, F. P.; GRISI-FILHO, J. H. H.; FERREIRA, F.; AMAKU, M.; DIAS, R. A.; TELLES, E. O.; HEINEMANN, M. B.; GONÇALVES, V. S. P.; FERREIRA NETO, J. S. Prevalence and risk factors for bovine brucellosis in Santa Catarina State, Brazil. Semina: Ciências Agrárias, Londrina, v. 37, n. 5, p. 3425-3436, 2016. Suplemento 2.

BORBA, M. R.; STEVENSON, M. A.; GONÇALVES, V. S. P.; FERREIRA NETO, J. S.; FERREIRA, F.; AMAKU, M.; TELLES, E. O.; SANTANA, S. S.; FERREIRA, J. C. A.; LÔBO, J. R.; FIGUEIREDO, V. C. F.; DIAS, R. A. Prevalence and risk-mapping of bovine brucellosis in Maranhão State, Brazil. Preventive Veterinary Medicine, London, v. 110, n. 2, p. 169-176, 2013.

CHATE, S. C.; DIAS, R. A.; AMAKU, M.; FERREIRA, F.; MORAES, G. M.; COSTA NETO, A. A.; MONTEIRO, L. A. R. C.; LÔBO, J. R.; FIGUEIREDO, V. C. F.; GONÇALVES, V. S. P.; FERREIRA NETO, J. S. Situação epidemiológica da brucelose bovina no Estado do Mato Grosso do Sul. Arquivo Brasileiro de Medicina Veterinária e Zootecnia, Belo Horizonte, v. 61, p. 46-55, 2009. Suplemento 1.

CHRISTIE, T. Eradication of brucellosis in Northern Ireland: field problems and experience. Veterinary Record, London, v. 85, n. 10, p. 268-269, 1969.

CLEMENTINO, I. J.; DIAS, R. A.; AMAKU, M.; FERREIRA, F.; TELLES, E. O.; HEINEMANN, M. B.; GONÇALVES, V. S. P.; GRISI-FILHO, J. H. H.;
FERREIRA NETO, J. S.; ALVES, C. J.; SANTOS, C. S. A. B.; AZEVEDO, S. S. Epidemiological situation of bovine brucellosis in the state of Paraiba, Brazil. Semina: Ciências Agrárias, Londrina, v. 37, n. 5, p. 3403-3412, 2016. Suplemento 2.

CRAWFORD, R.; HUBER, J.;ADAMS, B. Epidemiology and surveillance. In: NIELSEN, K.; DUNCAN, J. (Ed.). Animal brucellosis. Boca Raton: CRC Press, 1990. p. 131-151.

DIAS, J. A.; MÜLLER, E. E.; DIAS, R. A.; FREITAS, J. C.; AMAKU, M.; FERREIRA, F.; SILVA, M. C. P.; LÔBO, J. R.; FIGUEIREDO, V. C. F.; GONÇALVES, V. S. P.; FERREIRA NETO, J. S. Situação epidemiológica da brucelose bovina no Estado do Paraná. Arquivo Brasileiro de Medicina Veterinária e Zootecnia, Belo Horizonte, v. 61, p. 66-76, 2009a. Suplemento 1.

DIAS, R. A.; BELCHIOR, A. P. C.; FERREIRA, R. S.; GONÇALVES, R. C.; BARÃO. R. S. C.; SOUSA, P. R.; SANTOS, A. M. A.; AMAKU, M.; FERREIRA, F.; TELLES, E. O.; GRISI-FILHO, J. H. H.; HEINEMANN, M. B.; GONÇALVES, V. S. P.; FERREIRA NETO, J. S. Controlling bovine brucellosis in the State of São Paulo, Brazil: results of ten years of vaccination program. Semina: Ciências Agrárias, Londrina, v. 37, n. 5, p. 3505-3518, 2016. Suplemento 2.

DIAS, R. A.; GONÇALVES, V. S. P.; FIGUEIREDO, V. C. F.; LÔBO, J. R.; LIMA, Z. M. B.; PAULIN, L. M. S.; GUNNEWIEK, M. F. K.; AMAKU, M.; FERREIRA NETO, J. S.; FERREIRA, F. Situação epidemiológica da brucelose bovina no Estado de São Paulo. Arquivo Brasileiro de Medicina Veterinária e Zootecnia, Belo Horizonte, v. 61, p. 118-125, 2009b. Suplemento 1.

DOHOO, I.; MARTIN, W.; STRYHN, H. Veterinary epidemiologic research. Charlottetown: Atlantic Veterinary College, 2003. 706 p.

FLETCHER, R. H.; FLETCHER, S. W.; WAGNER, E. H. Clinical epidemiology: the essentials. $2^{\text {th }}$ ed. Baltimore: Williams \& Wilkins, 1998. 246 p.

GONÇALVES, V. S. P.; DELPHINO, M. K. V. C.; DIAS, R. A.; FERREIRA, F.; AMAKU, M.; FERREIRA NETO, J. S.; PORTO, T. B.; ALVES, C. M.; FIGUEIREDO, V. C. F.; LOBO, J. R. Situação epidemiológica da brucelose bovina no Estado de Minas Gerais. Arquivo Brasileiro de Medicina Veterinária e Zootecnia, Belo Horizonte, v. 61, p. 35-45, 2009a. Suplemento 1.

GONÇALVES, V. S. P.; RIBEIRO, L. A.; CALDAS, R. A.; FRANCISCO, P. F. C.; DIAS, R. A.; FERREIRA, F.; AMAKU, M.; FERREIRA NETO, J. S.; FIGUEIREDO, V. C. F.; LOBO, J. R.; BORGES, J. R. J. Situação epidemiológica da brucelose bovina no Distrito Federal. 
Arquivo Brasileiro de Medicina Veterinária e Zootecnia, Belo Horizonte, v. 61, p. 14-18, 2009b. Suplemento 1.

HOSMER, D. W.; LEMESHOW, S. Applied logistic regression. Hoboken: Wiley, 2000. v. 2, 528 p.

INLAMEA, O. F.; ROCHA, A. B.; FERREIRA, F.; GRISI-FILHO, J. H. H.; HEINEMANN, M. B.; DIAS, R. A.; TELLES, E. O.; GONÇALVES, V. S. P.; AMAKU, M.; FERREIRA NETO, J. S. Effect of vaccination in lowering bovine brucellosis in the state of Rondônia, Brazil. Semina: Ciências Agrárias, Londrina, v. 37, n. 5, p. 3493-3506, 2016. Suplemento 2.

KELLAR, J.; MARRA, R.; MARTIN, W. Brucellosis in Ontario: a case control study. Canadian Journal of Comparative Medicine: Revue Canadienne de Médecine Comparée, Ottawa, v. 40, n. 2, p. 119-128, 1976.

KLEIN-GUNNEWIEK, M. F. C.; AMAKU, M.; DIAS, R. A.; FERREIRA, F.; GITTI, C. B.; PEREIRA, L. A.; FIGUEIREDO, V. C. F.; LOBO, J. R.; GONÇALVES, V. S. P.; FERREIRA NETO, J. S. Situação epidemiológica da brucelose bovina no Estado do Rio de Janeiro. Arquivo Brasileiro de Medicina Veterinária e Zootecnia, Belo Horizonte, v. 61, p. 77-84, 2009. Suplemento 1.

LAGE, A. P.; ROXO, E.; MÜLLER, E.; POESTER, F.; CAVALLÉRO, J. C. M.; FERREIRA NETO, J. S.; MOTA, P. M. P. C.; GONÇALVES, V. S. P. Programa nacional de controle e erradicação da brucelose e da tuberculose animal (PNCEBT). Manual Técnico. Brasília: Ministério da Agricultura, Pecuária e Abastecimento, Brasília, 2006, $184 \mathrm{p}$.

LEAL FILHO, J. M.; BOTTENE, I. F. N.; MONTEIRO, L. A. R. C.; PELLEGRIN, A. O.; GONÇALVES, V. S. P.; FERREIRA, F.; DIAS, R. A.; AMAKU, M.; TELLES, E. O.; GRISI-FILHO, J. H. H.; HEINEMANN, M. B.; FERREIRA NETO, J. S Control of bovine brucellosis from 1998 to 2009 in the state of Mato Grosso do Sul, Brazil. Semina: Ciências Agrárias, Londrina, v. 37, n. 5, p. 3467-3478, 2016. Suplemento 2.

LUMLEY, T. Analysis of complex survey samples. Journal of Statistical Software, Los Angeles, v. 9, n. 8, p. 1-19, 2004.

MARVULO, M. F. V.; FERREIRA, F.; DIAS, R. A.; AMAKU, M.; GROFF, A. C. M.; GONÇALVES, V. S. P.; FIGUEIREDO, V. C. F.; LÔBO, J. R.; FERREIRA NETO, J. S. Situação epidemiológica da brucelose bovina no Estado do Rio Grande do Sul. Arquivo Brasileiro de Medicina Veterinária e Zootecnia, Belo Horizonte, v. 61, p. 93-102, 2009. Suplemento 1.
MIKOLON, A. B.; GARDNER, I. A.; HERNANDEZ DE ANDA, J.; HIETALA, S. K. Risk factors for brucellosis seropositivity of goat herds in the Mexicali Valley of Baja California, Mexico. Preventive Veterinary Medicine, Amsterdam, v. 37, n. 1-4, p. 185-195, 1998.

NEGREIROS, R. L.; DIAS, R. A.; FERREIRA, F.; FERREIRA NETO, J. S.; GONÇALVES, V. S. P.; SILVA, M. C. P.; FIGUEIREDO, V. C. F.; LOBO, J. R.; FREITAS, J.; AMAKU, M. Situação epidemiológica da brucelose bovina no Estado do Mato Grosso. Arquivo Brasileiro de Medicina Veterinária e Zootecnia, Belo Horizonte, v. 61, p. 56-65, 2009. Suplemento 1.

NICOLETTI, P. The epidemiology of bovine brucellosis. Advances in Veterinary Science and Comparative Medicine, New York, v. 24, n. 24, p. 69-98, 1980.

NOORDHUIZEN, J. P. T. M.; THRUSFIELD, M. V.; FRANKENA, K.; GRAAT, E. A. M. Application of quantitative methods in veterinary epidemiology. Wageningen: Wageningen Academic Publishers, 2001. $325 \mathrm{p}$.

OGATA, R. A.; GONÇALVES, V. S. P.; FIGUEIREDO, V. C. F.; LOBO, J. R.; RODRIGUES, A. L.; AMAKU, M.; FERREIRA, F.; FERREIRA NETO, J. S.; DIAS, R. A. Situação epidemiológica da brucelose bovina no Estado do Tocantins. Arquivo Brasileiro de Medicina Veterinária e Zootecnia, Belo Horizonte, v. 61, p. 126134, 2009. Suplemento 1.

OLIVEIRA, L. F.; DORNELES, E. M. S.; MOTA, A. L. A. A.; GONÇALVES, V. S. P.; FERREIRA NETO, J. S.; FERREIRA, F.; DIAS, R. A.; TELLES, E. O.; GRISIFILHO, J. H. H.; HEINEMANN, M. B.; AMAKU, M.; LAGE, A. P. Seroprevalence and risk factors for bovine brucellosis in the State of Minas Gerais, Brazil. Semina: Ciências Agrárias, Londrina, v. 37, n. 5, p. 3449-3446, 2016. Suplemento 2.

PAULIN, L.; FERREIRA NETO, J. O Combate à brucelose bovina: situação brasileira. Jaboticabal: Fundação de Estudos e pesquisas em Agronomia, Medicina Veterinária e Zootecnia, 2003. 154 p.

POESTER, F. P.; GONÇALVES, V. S. P.; LAGE, A. P. Brucellosis in Brazil. Veterinary Microbiology, Amsterdam, v. 90, n. 1-4, p. 55-62, 2002.

R DEVELOPMENT CORE TEAM - R: a language and environment for statistical computing, $\mathrm{R}$ foundation for statistical computing. Vienna: R Foundation for Statistical Computing, 2012. 
ROCHA, W. V.; GONÇALVES, V. S. P.; COELHO, C. G. N. F. L.; BRITO, W. M. E. D.; DIAS, R. A.; DELPHINO, M. K. V. C.; FERREIRA, F.; AMAKU, M.; FERREIRA NETO, J. S.; FIGUEIREDO, V. C. F.; LOBO, J. R.; BRITO, L. A. B. Situação epidemiológica da brucelose bovina no Estado de Goiás. Arquivo Brasileiro de Medicina Veterinária e Zootecnia, Belo Horizonte, v. 61, p. 27-34, 2009. Suplemento 1 .

SALMAN, M. D.; MEYER, M. E. Epidemiology of bovine brucellosis in the Mexicali Valley, Mexico: literature review of disease-associated factors. American Journal of Veterinary Research, Chicago, v. 45, n. 8, p. 1557-1560, 1984.

SIKUSAWA, S.; AMAKU, M.; DIAS, R. A.; FERREIRA NETO, J. S.; MARTINS, C.; GONÇALVES, V. S. P.; FIGUEIREDO, V. C. F.; LOBO, J. R.; FERREIRA, F. Situação epidemiológica da brucelose bovina no Estado de Santa Catarina. Arquivo Brasileiro de Medicina Veterinária e Zootecnia, Belo Horizonte, v. 61, p. 103108, 2009. Suplemento 1.
SILVA, N. S.; GROFF, A. C. M.; VIDOR, A. C. M.; GRISI-FILHO, J. H. H.; HEINEMANN, M. B.; DIAS, R. A.; TELLES, E. O.; GONÇALVES, V. S. P.; AMAKU, M.; FERREIRA, F.; FERREIRA NETO, J. S. Epidemiological situation of brucellosis after implementation of the vaccination program in Rio Grande do Sul State, Brazil. Semina: Ciências Agrárias, Londrina, v. 37, n. 5, p. 3519-3530, 2016. Suplemento 2.

SILVA, V.G. S. O.; DIAS, R.A.;FERREIRA, F.;AMAKU, M.; COSTA, E. L. S.; LOBO, J. R.; FIGUEIREDO, V. C. F.; GONÇALVES, V. S. P.; FERREIRA NETO, J. S. Situação epidemiológica da brucelose bovina no Estado de Sergipe. Arquivo Brasileiro de Medicina Veterinária e Zootecnia, Belo Horizonte, v. 61, p. 109-117, 2009. Suplemento 1.

THRUSFIELD, M. Veterinary epidemiology. $3^{\text {th }}$ ed. Hoboken: Wiley-Blackwell, 2007.

VILLAR, K. S.; AMAKU, M.; DIAS, R. A.; FERREIRA NETO, J. S.; BENITEZ, F.; GONÇALVES, V. S. P.; FIGUEIREDO, V. C. F.; LOBO, J. R.; FERREIRA, F. Situação epidemiológica da brucelose bovina no Estado de Rondônia. Arquivo Brasileiro de Medicina Veterinária e Zootecnia, Belo Horizonte, v. 61, p. 85-92, 2009. Suplemento 1. 